\title{
Influences of Racial Science in Hitler's Europe
}

\begin{abstract}
Ana A. Susnjar
“The 'Final Solution' you see is really final because people who are converted can yet be, in secret, Jews; people that are expelled can yet return. But people who are dead, will not reappear."
\end{abstract}

- Raul Hilberg 1

The origins of the Holocaust cannot be identified as a single event or decision, rather it is an evolving story that catastrophically left an eternal blood stain on human history, an event in history that will never be forgotten, nor can be forgotten. The classification of living organisms of plants and animals in the world evolved into the idea of reevaluating the human race in nature. Thus, the classification of human beings began and would inevitably segregate the world and evolve into racial theory (or racial science); by 1900, racial thinking had become "science." The basis and justification of the Nazi Regime's extreme ideology to begin, and carry out the industry to destroy the European Jewry was considered, "a public health measure." 2 The combination of racial science and eugenics became fundamental in the Third Reich's ability to implement legislation and coerce the population into believing the Jews and other groups were impeding on the possibility of German Lebensraum and therefore, needed to be removed. ${ }^{3}$ Though it is important to acknowledge that many were resistant, and many tried to prevent the atrocities, the power of the Third Reich was greater. Some eugenicists in Germany, America, and other countries debated the "scientific research" distinguishing Jews from other Europeans; these eugenicists argued that the distinction was not possible or clear. Thus, the antisemitic influence and the power of the Third Reich removed those people from their work in

\footnotetext{
1 "Raul Hilberg on the destruction of the European Jews" https://www.youtube.com/watch?v=bQGFbWKhGfo 2 Eric Ehrenreich, Nazi Ancestral Proof: Genealogy, Racial Science, and the Final Solution (Bloomington: Indianan University Press, 2007), 1-13.

${ }^{3}$ Michael Burleigh, Moral Combat (New York: HarperCollins Publishers, 2011), 24-35.
} 
Germany. ${ }^{4}$ The promotion of science under antisemitic influences must be seen as a part of the broader effort to justify the persecution and ultimate removal of Jews in Europe. The purpose of this paper is to provide evidence for the fundamental influence that the promotion of racial science, eugenics, and bio-politics during the Third Reich had on the Holocaust.

Prior to 1933, racial scientific claims rarely were recognized for scientific validity. German racial scientists began by initially identifying Volk as, "a group of persons composed of a similar mixture of "comparable races" sharing a common culture." 5 This resulted in Jews being identified as a Volk rather than a race, and by the time Nazis came to power, claimed that "Jewish culture, not physical characteristics, pointed up the primary racial difference." ${ }^{\prime}$ The ambiguity of defining race and the failed attempt to identify Jews as a race did not pose a threat to Jews prior to 1933. Racial science did not have an imperative effect on Germany until after 1933 when Nazi powers promoted the antisemitic "scientific" research that was carried out by Eugen Fischer and other scientists. He described that there is an instinctive feeling of differences that are physical and mental between Jews and Europeans. Similar to Fischer, Otmar Freiherr von Verschuer argued Jews were a mental "race."7 Hans F.K Günther propagated the idea of the superiority of the "Aryan" race and similar to most racial anthropologists in Germany, helped develop the belief in a racial "consciousness" that persisted beyond 1933. It is through these claims that society was viewed to be a construction of the Volk and resulted in the segregation of the Volk into "valuable" and "less valuable." As a result, Jews were simultaneously regarded as a foreign race and considered racially alien. ${ }^{8}$ The alienation of Jews gave the Nazis the ability to coerce its people into believing that Jews threatened cultural and hereditary damage. The idea of Jews being "racially alien" brought forward other ideas to further segregate Jews from Europe; the notion of Jews wandering through Europe, homeless.

${ }^{4}$ Robert Jay Lifton, The Nazi Doctors (New York: Basic Books, 1986), 37.

${ }^{5}$ Eric Ehrenreich, Nazi Ancestral Proof: Genealogy, Racial Science, and the Final Solution (Bloomington: Indianan University Press, 2007), 3-4.

6 Ibid. 4.

7 Ibid. 8.

${ }^{8}$ Rory Yeomans and Anton Weiss-Wendt, Racial Science in Hitler's New Europe 1938-1945 (Lincoln: University of Nebraska Press, 2013), 7. 
Arthur de Gobineau argued that the failure of societies was a direct result of racial degeneration. Degeneration when applied to people, according to Gobineau, was the loss of intrinsic value: the people no longer had the same blood in its veins. That is, society is, "great and brilliant only so far is it preserves the blood of the noble group that created it"9 As a result, the "fear" of miscegenation became a danger and the fear promoted by Nazis allowed for legislation to pass preventing marriage between Jews and non-Jews to prevent the 'mixing' of blood. The ideas of Gobineau and other racial science theories became embodied in the Nuremberg Laws which gave the Nazis their ability to begin the destruction of Jews. The laws established a fixed hierarchy of race ranging from "Germans," to Mischlinge, to "full Jew." The basic principles of the laws intended to "institutionalize a universal, smoothly functioning, and predictable system of racial definition, inclusion, exclusion, and separation." 10 This continued through the regime and the basic principles of "racial and biological science" in Germany echoed throughout the Third Reich.

Ultimately, racial theory led to racist eugenic ideology. The eugenics principles became foundational to political and social policies during the Third Reich. Initially, eugenicists put forward that Germany's defeat was due to: "national degeneracy, influences of racial impurity, declining birth rates amount the intelligentsia and economically prosperous, and the antieugenic polices associated with socialist egalitarianism." 11 Racist eugenic ideology was essential in the creation of the political conditions necessary to allow the mistreatment of Jews. Representations of propaganda adapted around the political conditions and became an outlet to promote the Nazi ideology of Jews being racially different and a threat to Lebensraum. Anti-Jewish propaganda ranged from crass forms to appeal to the "less intellectually discerning" to educated Germans with higher intellectual standards. Various forms of images, newspapers, film, and other media targeted the racial threat Jews represented. The Reich Ministry of Propaganda published the book, The Jews among the Peoples: Studies on the Jewish Question in the Contemporary World which aimed to promote research on "the origins and growth of critical opposition against alien Jewish elements among all peoples," as well as attempted to eliminate the conflict between Jews and its

\footnotetext{
${ }^{9}$ Arthur de Gobineau, The Inequality of Human Races (New York: G. P Putnam's Sons, 1915), 23-36

${ }^{10}$ Alan E. Steinweis, Studying the Jew (Cambridge: Harvard University Press, 2009), 42

${ }^{11}$ Francis R. Nicosia, Medicine and Medical Ethics in Nazi Germany: Origins, Practices, Legacies (New York: Berghahn Books, 2002), 33.
} 
"host peoples." 12 The German population became susceptible to the antisemitic ideologies and through the perpetration of propaganda the Nazis were able to further their progress towards the "Final Solution."

Eugenics in its evolving discourse throughout the Third Reich provided a biological justification to stop caring for the mentally ill, and anyone the regime viewed inadequate. The discourse of eugenics reflected the idea of Rassehygiene (racial hygiene) which resulted in atrocities of forced sterilization and euthanasia, medical experiments in camps, and ultimately murder. The separation between "positive" and "negative" eugenics illustrate the embodiment of antisemitic influences within Germany. "Negative" eugenics embodied the biomedical vision of "purification of the nation's body" and the "eradication of morbid hereditary dispositions." In contrast, "positive" eugenics encouraged large families and constructive health practices among "Aryan" couples, and the justification of "positive" eugenics was that generations would change, and that the German people would live forever. ${ }^{13}$ The Physicians' Law of 1935 gave physicians the legal right to carry out sterilization and euthanasia aimed to preserve and improve the general health of the German Volk. The forced sterilization gave value to the German state's "public health concern" which continued in the camps. In retrospect, the hygienic measures throughout the German Nazi state during the Third Reich could be seen as "positive" with negative consequences-what Nazis saw as what needed to be done verses the negative reality of what was done.

While the concentration camps harbored many atrocities, experiments in the camps was the result of racial "science." Sterilization and castration experiments in Auschwitz by doctors Carl Clauberg and Horst Schumann directly mirrored expressions of racial theory and policy. ${ }^{14}$ Auschwitz became a paradigm for "scientific" experimentation; experiments of sterilization and castration, "anthropological research," and most notoriously, Dr. Josef Mengele's "research" on twins and dwarfs. The enthusiasm most physicians that took to experimentation and medical killings directly relates to the effect antisemitic influence had on science during the Nazi regime. There is a point when physicians believed their work

\footnotetext{
12 Alan E. Steinweis, Studying the Jew (Cambridge: Harvard University Press, 2009), 102.

${ }_{13}$ Robert Jay Lifton, The Nazi Doctors (New York: Basic Books, 1986), 42

14 Ibid. 269-383
} 
was for a purpose, the purpose to 'cleanse' the German race and to take their place towards the "Final Solution."

Consequently, the euthanasia and T4 (Tiergartenstrasse 4) program coexisted with forced sterilization. The organized killing of "life unworthy of life" developed into one of the early stages of mass murder within Germany. The euthanasia program evolved into an industry to remove anyone who would 'dilute' the quality and strength of German blood. However, for the Jews, the general criteria for medical killing did not apply to them. There was no need for "special consultations or discussions" rather, the elimination of Jewish inmates in the institutions in Germany was "the logical consequence" of the solution to the Jewish problem. Jewish mental patients to the Nazis were unique in that they could “embody both 'dangerous genes' in an individual medical sense, and 'racial poison' in a collective ethnic sense."15 The phrase "the Final Solution to the Social Problem" coined by social historian Karl Heinz Roth condemns how social policy was conflated by antisemitic eugenics. ${ }^{16}$ That is, the extension of sterilization to euthanasia marked an unequivocal link to the Holocaust. Throughout the functions of the camps, many Jews were subject to experimental variations that were cruel and often fatal experiments.

Joseph Goebbels in June 1943 said that the Jews' "disappearance" from Europe was imperative to Germany because of their "inner essence and racial instinct" determines their behavior - "the Jew destroys states and peoples. There is only one remedy: the radical extinction of the danger itself." 17 Goebbels directly related science to the Jews and their inevitable death. During the reign of Hitler, the notion of race and space became conflated to Hitler and he saw that the living space for "Aryans" was compromised by Jews and other groups-who he thought wanted to weaken, and destroy German strength. ${ }^{18}$ Lebensraum became the core ideology of the Nazi Regime that encompassed the notion of biopolitics. Friedrich Ratzel's interpretation of Darwin's work argued for the "violent struggle between

\footnotetext{
15 Ibid. 43, 66

16 Paul Weindling "Genetics, Eugenics, and the Holocaust” Biology and Ideology from Descartes to Dawkins. edited by Denis R. Alexander and Ronald L. (Chicago: University Chicago Press, 2010), 207.

17 Rory Yeomans and Anton Weiss-Wendt, Racial Science in Hitler's New Europe 1938-1945 (Lincoln: University of Nebraska Press, 2013), 357

18 Doris L. Bergen War \& Genocide: A Concise History of the Holocaust (Lanham: Rowman \& Littlefield Publishing Group, Inc), 52.
} 
species for territory." Ratzel's published work Lebensraum and the influence of antisemitism within Germany, led to the popularized notion of "survival of the fittest" that reflected Nazi ideology. The pursuit of living space became an inevitable racial struggle for "existence that was driving human evolution forward." ${ }^{19}$ The Wannsee Conference of 1942 brought together all the aspects of biopolitics to "cleanse" German living space of Jews in an ideological extremity that emphasized the Nazi concern of Volkstumskampf (racial struggle). The "evacuation of Jews to the East" that was the euphemism used to describe the execution of Jews during the protocol mirrors Grobineau's notion of race as a moving force in history and Darwin's theory and became the justification for the "final remnant since it will undoubtedly consist of the most resistant portion, have to be treated accordingly, because it is the product of natural selection and would, if released, act as the seed of a new Jewish revival (see the experience of history)." 20 The concepts of people and race influenced racial superiority of "Aryans" which was directly influenced by bio-politics. That is, the physical elimination of 'racial aliens' was necessary for the Volksgemeinschaft (the community of the people). The embodied Nazi ideology of race and space reflected antisemitism and "Aryan" supremacy, eugenics and nationalism; the biological process of "relocation to the East," and removing the Jewish race from Europe would, through the prism of racial science, "cleanse" the "Aryan" race and create the supreme German race.

It is, without mistake, that racial theory under the heavy influence of antisemitism developed into the broader effort to eliminate the Jews from Europe. The evolving of racial theory and eugenics was instrumental in developing Nazi ideology: the supremacy of the "Aryan" race needing living space to grow and strengthen, and the Jews as a racial threat. The early stages of "research" surrounding racial science and eugenics allowed the Nazi regime to selectively manipulate and form their own notion of "science." The basic principles of eugenics were fundamental in the justification both politically and scientifically to remove the Jews from Europe. It is with the antisemitic influence science informed legislation of sterilization, propaganda against Jews, experiments in the camps, and core ideologies of the Nazi regime. The Holocaust received its "scientific" legitimacy

\footnotetext{
19 Rory Yeomans and Anton Weiss-Wendt, Racial Science in Hitler's New Europe 1938-1945 (Lincoln: University of Nebraska Press, 2013), 8

${ }^{20}$ Avalon Project at Yale Law School, "Wannsee Protocol, January 20, 1942" Lillian Goldman Law Library. http://avalon.law.yale.edu/imt/wannsee.asp (accessed April 4, 2016).
} 
through the promotion of racial science, eugenics, and bio-politics. There is not a single event that leads to the Holocaust, rather it is the overlapping concepts that intertwine throughout the Nazi regime. 


\section{Works Cited}

Avalon Project at Yale Law School, “Wannsee Protocol, January 20, 1942" Lillian Goldman Law Library. http://avalon.law.yale.edu/imt/wannsee.asp (accessed April 4, 2016).

Burleigh, Michael. 2011. Moral Combat: Good and Evil in World War II. New York: HarperCollins Publishers,

Ehrenreich, Eric. Nazi Ancestral Proof: Genealogy, Racial Science, and the Final Solution. Bloomington: Indiana University Press, 2007. Accessed April 4, 2016. ProQuest ebrary.

Gobineau, Arthur de. 1915. The Inequality of Human Races. Translated by Adrian Collins. New York: G. P Putnam's Sons.

L., Bergen Doris. 2009. War \& Genocide: A Concise History of the Holocaust. Second Edition. Lanham: Rowman \& Littlefield Publishing Group, Inc.

Longerich, Peter. Holocaust. Oxford, GB: Oxford University Press, 2010. Accessed April 4, 2016. ProQuest ebrary.

Lifton, Robert Jay, 1926-. The Nazi Doctors. New York :Basic Books, 1986.

Nicosia, Francis R., and Jonathan Huener. 2002. Medicine and Medical Ethics in Nazi Germany: Origins, Practices, Legacies. New York: Berghahn Books.

Rory Yeomans and Anton Weiss-Wendt. 2013. Racial Science in Hitler's New Europe, 19381945. Lincoln: University of Nebraska Press.

Steinweis, Alan E.. Studying the Jew. Cambridge, US: Harvard University Press, 2009. Accessed April 4, 2016. ProQuest ebrary. 
Weindling, Paul. 2010. “Genetics, Eugenics, and the Holocaust. Biology and Ideology from Descartes to Dawkins. edited by Denis R. Alexander and Ronald L. Numbers, 192- 215. Chicago: University Chicago Press. 